\title{
Measuring and Mismeasuring Discrimination against Visible Minority Immigrants: The Role of Work Experience
}

\author{
Yoko Yoshida \\ McGill University \\ yoko.yoshida@mail.mcgill.ca
}

Michael R. Smith

McGill University

michael.smith@mcgill.ca

\begin{abstract}
There are two methods for estimating the earnings disadvantage of groups: the residual difference method and the Oaxaca-Blinder decomposition. Each method infers disadvantage from differences in earnings of visible minority immigrants and other Canadians, after controls for human capital and job characteristics. We: i) summarize the logic of these methods; ii) critically examine the character of the experience measures used in most of the research; iii) apply the residual difference method to the Workplace and Employee Survey to show how a more thorough approach to the measurement of work experience modifies estimates of earnings disadvantage.
\end{abstract}

Key Words: wages, work experience, visible minority immigrants

\section{Résumé}

Deux méthodes sont utilisées pour estimer le désavantage salarial de groupes: la 'méthode de difference résiduelle' et la 'décomposition Oaxaca-Blinder'. Selon la logique de ces méthodes, après avoir contrôlé pour les différences du capital humain, le désavantage des immigrants de minorités visibles relatifs aux autres Canadiens est la différence nette du salaire. Dans cette article nous : $i$ ) décrivons la logique de ces méthodes ; ii) examinons la qualité des indicateurs d'expérience utilisés; iii) analysons les données de l'Enquête sur le milieu du travail et les employés. Notre conclusion est que le fait d'inclure d'indicateurs améliorés de l'expérience a pour effet de modifier l'estimation du désavantage.

Mots-clés: salaries, experience, immigrants de minorities visibles 
There is a large body of Canadian research on the relative earnings of members of visible minority groups and of immigrants. Two procedures are used to generate estimates of earnings disadvantage. Sociologists and some economists use a residual difference method. It involves the introduction into a regression equation of one or more dummy variables identifying a disadvantaged group along with measures of human capital and other relevant controls. If, after adding controls, there is a significant effect of the dummy variable on earnings, that effect is treated as a measure of disadvantage. While not all papers are explicit on this, "disadvantage" is often viewed as an indicator of discrimination. Economists more typically use an OaxacaBlinder decomposition technique in which separate equations are estimated for the groups thought to be advantaged and disadvantaged, the coefficients estimated for one group are subtracted from those estimated for the other group and if, say, the effect of human capital on earnings is larger for one group than for the other, the difference estimated provides the measure of disadvantage or discrimination.

Each technique has its strengths and weaknesses. Nonetheless, their fundamental logic is the same.

1. Accept that productivity varies with a set of standard indicators of human capital: education, experience, and language skills.

2. In the case of the residual difference method, put the indicators into an equation along with a dummy or dummies for the (hypothetically) disadvantaged group or groups. Or, in the case of the Oaxaca-Blinder decomposition, put the human capital indicators into two or more equations, one for each group of interest.

3. Assign to discrimination any visible minority immigrant earnings disadvantage after controls for human capital using either of the two methods. This discrimination could take place in access to jobs, or within jobs, or both. Conversely, the absence of differences in earnings after controls for human capital would indicate the absence of discrimination.

4. If the disadvantage disappears after the addition of controls for job characteristics, infer that there is discrimination in access to jobs, but not within jobs.

5. If, after controls for job characteristics, the disadvantage persists, infer the existence of discrimination both within jobs and in access to them.

This logic, then, can either lead to the conclusion that discrimination is present or not present. Examples in Canadian research of the use of these methods to estimate the earnings disadvantage of visible minority immigrants are de Silva (1992, 1997), Li (2000, 2001), Reitz (2001), Hum and Simpson (1999), Pendakur and Pendakur (1998, 2002), Wanner (1998), Swidinsky and Swidinsky (2002), and AdamutiTrache and Sweet (2005).

Key findings from this research are that visible minority immigrant males earn less than native-born white males but visible minority females do not earn less than 
native-born white females. Immigrant whites of both genders tend to earn the most. ${ }^{1}$ Another key finding is that the disadvantage of native-born visible minority members is complicated. Pendakur and Pendakur (2002) report consistent disadvantage across five censuses for males. They also show that there are wide variations in the situations of different groups. For example, their analysis reveals that while black males were disadvantaged in all censuses, which was not the case for other groups. Japanese-Canadians were advantaged in four out of five census years and not disadvantaged in the fifth and earliest census. Chinese-born were disadvantaged in three censuses, advantaged in one, and neither advantaged nor disadvantaged in the remaining census. Using the Survey of Labour and Income Dynamics (SLID) Hum and Simpson (1999:392) found that "with the exception of Black men, there is no significant wage gap between visible minority and non-visible minority members for native-born workers."

Much of the disadvantage of visible minority immigrant males originates in lower returns to experience and education than those of other population categories. The premium to their overseas experience is approximately zero. The premium to a diploma received overseas is lower than the premium received for a Canadian diploma. Note, however, that the visible minority immigrant disadvantage in returns to education disappears when their education is completed in Canada. Controlling for kinds of job reduces the difference between the earnings of visible minority immigrant males and their white counterparts (whether native-born or immigrant), but some studies find that a difference persists. The bulk of the evidence, then, is consistent with a discrimination interpretation.

In the detailed analyses in this paper we confine our attention to visible minority immigrant males. Because other studies find little or no disadvantage and because our own analysis of the data set that we use finds no disadvantage we do not model the pay-determination of women. Nonetheless, to establish comparability with other studies and to illustrate our broader point on the bias introduced into disadvantage estimates by the measurement of experience commonly used in the research, women are included in our first two tables. Our other exclusion from the detailed analyses is native-born visible minority members because there are not enough of them in our sample.

\section{The Problem of Measurement}

The bulk of the relevant Canadian research that estimates the quantity of the earnings disadvantage of visible minority immigrants uses census data. These are data of a very high quality indeed. Moreover, even with public use samples, the number of

1. The standard interpretation is that since women, whether white or visible minority, immigrant or native-born, are poorly paid there is less room for earnings disadvantage. This may be correct. But it has not yet been subject to careful empirical scrutiny. 
cases to work with is large - for example, about 350,000 in Reitz's (2001) use of the 1996 census. Nonetheless, we would argue that, despite its quality and the size of the sample it makes available, the census is a particularly poor source if the intention is to estimate magnitudes of discrimination. This is because the census lacks a measure of experience.

There is no question on work experience in the census information so schooling duration is used to construct what Reitz (2001:357) calls "the usual derived measure" - in fact, the "Mincer proxy": age minus 5 or 6 (depending on the age at which schooling is assumed to start), minus years of education. This is, usually, a potential maximum number of years of experience. It assumes that individuals are continuously employed after their schooling ends. ${ }^{2}$ In the literature on gender earnings disadvantage it has been recognized that this is a biased measure. Many more women than men withdraw from employment to raise children so it clearly overestimates mean years of female employment by more than it overestimates male years of employment. Some effort has been made to correct the bias in the census (e.g., Kidd and Shannon, 1997). Drolet (2002) emphasizes the value of a more adequate experience measure in her analysis using the WES. That this is also likely to be a problem when comparing immigrants to the native-born is less widely recognized.

The Mincer proxy is used in an attempt to measure cumulative work experience. Hum and Simpson (2004) produce a markedly improved analysis by including a much better measure of the same concept. But the problems with measures of experience go beyond the inadequacy of the Mincer proxy. Work experience would be expected to increase pay because it increases individual productivity. The cumulative number of years of work on its own, however, is likely to be a misleading indicator of the amount of productivity-enhancing work experience. There are also the effects on experience of changes of employer and job.

Many of these will no doubt involve a cumulative process in which the skills demanded at each new employer or job build on what was learned at the previous employer or job. In such cases, cumulative years of experience would be a good indicator of an employee's capacity to be productive. But we know that there is a great deal of turbulence in employment. Job creation and destruction are pervasive in capitalist economies, including Canada (Davis, Haltiwanger, and Schuh, 1996; Baldwin, Dunne, and Haltiwanger, 1998). Greater trade exposure appears to have increased both (Klein, Schuh, and Triest, 2003). Where someone shifts between employers and jobs because part or all of their workplace ceases operation, by definition, the specific skills that added to their productivity become irrelevant. Moreover, if that person is compelled to switch industries - which is likely to be the case where job loss was trade-initiated - previously acquired skills that were general within the initial industry of employment may become irrelevant too. Total years of employment

2. Employment during schooling means that in some cases the Mincer proxy underestimates total experience. It is clear, however, that the aggregate effect of this measure is to produce an overestimate. 
- cumulative experience - certainly overstates the real, productivity-enhancing, work experience of some proportion of employees. Our guess is that the proportion is quite large.

The final problem with measures of experience is that they assume that all jobs provide the same opportunities for skill enhancement. Even if correctly measured, cumulative years of experience treats the learning through experience of a lawyer as equivalent to that of a short-order cook. This is surely implausible. Some significant part of the labour force moves through jobs that demand little of them and involve negligible consecutive skill development.

Part of what is at issue here is access to training. Whether on-the-job, in classrooms at work, or in courses taken outside work, whether specific or general, training amounts will vary between jobs (e.g., Duncan and Hoffman, 1979:596-598; Barron, Berger, and Black, 1997). In most professions, skill upgrading is continuous through an entire employment history, or through most of it. To generalize the characteristics of professional employment to the rest of the labour force would be imprudent. But that is precisely what a measure of experience based only on cumulative years of employment does. So, when controls for occupation and industry are added to an equation they will to some degree tap a training effect. Professionals with twenty years of work experience in the financial services industry or parts of the education sector probably earn more than other respondents with similar experience in part because on-the-job and other training forms have been a continuous element of their employment history. ${ }^{3}$ This has implications for the interpretation of ethnicity coefficients in equations that control for industry and occupation.

The general point made in this section is the following: most of the relevant research uses the census; the use of the census to estimate the magnitude of discrimination using either the residual difference method or an Oaxaca-Blinder decomposition requires unbiased measures of human capital; but the census probably does not provide an unbiased measure of cumulative work experience. Nor does cumulative work experience exhaust what is likely to be productivity-relevant in someone's employment history. Heckman (2004:104) has made a similar point about the measurement limitations of research on discrimination, with some force.

\section{Reconsidering the Earnings of Visible Minority Immigrants}

Consider, in more detail, the biases introduced by the reliance on the Mincer proxy to estimate visible minority immigrant earnings disadvantage. Insofar as immigration involves transitional periods of prolonged job search - and that is surely the case

3. The effect of employer-provided training is not, however, straightforward. Whether employer-provided training is associated with higher pay - and at what point in the employee's career - is likely to be influenced by whether the training provides specific or general skills. The classic statement of this issue is Becker (1975). In this analysis we set aside this complexity. 
for many family-class or asylum-seeking migrants - it is likely to systematically overestimate the cumulative work experience of visible minority immigrants as compared to both native-born Canadians and white immigrants (since the latter are less likely to fall into the family-class or refugee categories). ${ }^{4}$ So-called "economic class" migrants, who ought to have less difficulty integrating into the labour market, were already exceeded by family-class immigrants and refugees by the end of the 1970s (Reitz, 1998:78). The share of economic-class migrants has since risen - but is still exceeded by the other immigrant categories if family-class immigrants, spouses and dependents of economic-class migrants, and refugees are summed. ${ }^{5}$ All this is to say that the proportion of immigrants for whom the transition to employment is likely to be prolonged and difficult is significant. As far as we can tell, in most of the Canadian research using the census to explore differences in earnings by ethnicity and immigrant status, the implications of problems of the Mincer proxy go unconsidered. A recent paper by Hum and Simpson (2004:131-132) makes precisely this point and, using the Survey of Labour and Income Dynamics, shows that the earnings disadvantage of immigrant men is reduced where a direct measure of experience is used rather than the Mincy proxy.

Even with an adequate measure of cumulative years of work experience there are other problems. The specific skills of immigrant adults are lost when they arrive in Canada. Since their move is to a richer country with (for the most part) more sophisticated capital equipment, the value of skills that were general and therefore transferable across employers and equipment in their country of origin is reduced. Some of those skills are likely to be, effectively, specific to their previous employment and of no value in Canada. We know, as a matter of fact, that a significant proportion of adult visible minority immigrants with work experience when they arrived in Canada not only switch employers but also switch occupations (Boyd and Thomas, 2002; Renaud and Cayn, 2006).

Suppose, however, that an immigrant arrives as an adult and moves promptly into a job that exploits skills acquired in the country of origin. There still may be a problem. Training will normally be offered in one of the official languages. Offers of productivity-enhancing training are likely to be delayed until the employee acquires the required language skills. In fact, of course, language difficulties are likely to channel many immigrants into jobs that provide little opportunity for training. Adult immigrants are, indeed, less likely to receive training (Hum and Simpson, 2003, 2004; Yoshida and Smith, 2005). ${ }^{6}$

4. Wanner (2003) shows differences in labour market outcomes across immigrant classes.

5. The totals for 2001 can be found at http://www.statcan.ca/english/freepub/89-611-XIE/tables/ suptableb.htm

6. Hum and Simpson reject the hypothesis that language is an obstacle to immigrant training (2003:486487). We think that they do so prematurely. They rest their conclusion on responses to a question that asks the reason for not taking training. Few adult immigrants cited language. They said that training was "not offered," "inconvenient," that they were "too busy" or that training was "too expensive." The last category is beside the point. Employer-provided training would not require employee pay- 
The use of the census and the Mincer proxy means that the application of either the residual difference method or of the Oaxaca-Blinder decomposition probably overestimates the earnings disadvantage of visible minority immigrants because it overestimates their cumulative work experience. The earnings disadvantage is likely to be overestimated because, on average, the difference between the maximum and the actual years of employment is larger for visible minority immigrants than for the native-born. The effect of this would be to misleadingly reduce the estimated rate of return to cumulative experience for visible minority immigrants relative to that of the native-born. There may be further sources of error where analyses fail to recognize that much work experience acquired in the country of origin is likely to have no value in Canada, and that language deficiencies are a barrier to training - pushing immigrants in their first years in Canada away from jobs for which productivity-enhancing training is a prerequisite. For all these reasons, in what follows we focus on the role of experience in the earnings determination of immigrants and the native-born.

\section{A Different Data Set}

We analyze data from Statistics Canada's Workplace and Employee Survey (WES). The WES has two distinctive characteristics. It involves interviews with both managers and a sample of employees within the workplaces managed, and panel data is generated on both workplaces and employees. The research on earnings differentials by ethnicity and immigrant status cited earlier is, however, entirely cross-sectional. Since our objective is to examine the premises of that research we confine our analysis in this paper to the first, 1999, cross-section. ${ }^{7}$ That survey generated 5440 employer responses and 24,938 employee responses. ${ }^{8}$

For our purposes, the WES has two advantages over alternative data sets. First, it has better measures of experience. The employee survey has this question: "Considering all the jobs you have held, how many years of full-time working experience do you have?" Imperfect recollection will have caused measurement error. Still, the question invites respondents to sum working experience across jobs. Those who have been out of the labour force for ten years while child rearing, or for two years while

ment. More importantly, these responses probably reflect the character of immigrants' jobs. It is likely that training was not offered, was offered inconveniently, or that work schedules did not allow training because immigrants were in jobs whose employers had little interest in upgrading employee productivity through training. Note also that Yoshida and Smith report that the pay-off to training for employed visible minority immigrants was as large as that for native-born whites.

7. We have also performed exploratory analyses on the 2000 survey. Not surprisingly, the results seem similar.

8. Details of the survey can be found in Guide to the Analysis of the Workplace and Employee Survey 1999, Business and Labour Market Analysis Division and Labour Statistics Division, Statistics Canada. When the employer and employee responses are linked, the usable N's are reduced by the existence of workplaces for which no employee responses exist and employees for whom no workplace responses exist. 
receiving language training and job-hunting after immigration, are likely to have adjusted their responses accordingly. Respondents were also asked when they started working with their current employer and when they started working in their current job. There are, then, good measures of cumulative work experience, of experience with the current employer, and experience at the current job.

The WES experience measure may also be superior to the measure available from SLID, used by Hum and Simpson (2004). That measure, oddly, treats 6 months of work in a given year as a full year of employment. (See the relevant section of the SLID data dictionary at http://www.statcan.ca/english/SLID/t05200. htm\#yrgt6m11.) The SLID measure systematically overestimates the number of years of work experience for the seasonally employed. The WES experience question is less likely to have that weakness.

Unlike the census and SLID, the WES also contains direct questions on employer-provided training. Those questions yield three measures that we use: on-the-job training; whether the respondent received classroom training; and, if he or she did, how many separate courses were taken. Training, we argue, is an attribute of work experience that is pertinent in pay determination. Responses on training received may provide us with more precise information on the quality of the work experience than would knowledge of the broad occupation of the respondent alone.

The second advantage of the WES is that it provides better data on employer characteristics than either the census or the SLID. Managers are usually better informed on the characteristics of the output of the workplace (that determines its assignment to one or another industry), on company size, on the aggregate investment in training by the firm, and on other employment or job characteristics likely to be associated with pay. The WES allows us to more effectively control for industry and for firm characteristics.

Despite these two major advantages, we do not claim that the WES allows an accurate estimate of pay discrimination against visible minority immigrants - or, for that matter, a categorical argument that such discrimination does or does not exist. We discuss data set limitations later in the paper.

\section{Measures, Sample Selection, and Model Specification}

Our dependent variable is the natural logarithm of the hourly wage rate. In research using the census the usual dependent variable is total annual earnings. That total may be produced by substantially different numbers of hours worked (Christofides and Swidinsky, 1994:35). Even within a sample confined to full-time, full-year employees, annual earnings will vary with both basic hours worked (because each threshold specifies a minimum, above which there is considerable variation) and with overtime. Two people with the same total pay may have different wage rates. Having to work longer for the same total pay would constitute disadvantage. Consequently, 
as in other research using a data set containing a measure of it, we focus on hourly pay. Our main independent variable of interest is summarized in visible minority/immigration status dummies. To simplify presentation, in what follows we call this the IVOI - independent variable of interest.

We exclude female employees from the detailed analyses because, as noted earlier, visible minority immigrant women do not earn less than the native-born. Among males our analysis is applied to two samples: full-time (32 or more hours per week), full-year (52 weeks of work in the survey year) employees; and all effective labour market participants, which we define as employees who earned $\$ 1,000$ or more in the reference year, no matter how many hours or weeks they worked. We include a separate analysis of full-time, full-year employees because we assume that this indicates a strong commitment to labour market participation. In the analyses of effective labour market participants that include controls for industry, occupation, and firm characteristics we include controls for hours worked and weeks worked. Parttime, part-year jobs are likely to be systematically different from full-year, full-time jobs in ways unlikely to be fully captured by industry-related controls. Except for our first descriptive table we also exclude visible minority native-born Canadians; there are not enough of them in our sample for useful analysis. And, because of their distinct economic position, we exclude Aboriginals.

Descriptive information on the independent variables used in the analysis is provided in the Appendix Table. All except three are drawn directly from questions in the WES survey. The exceptions are the Mincer proxy, language skills, and location of education. The Mincer proxy was constructed as described above, using estimates of years of education associated with different levels of certification drawn from Ferrer and Riddell (2002). The indicator of language skills was constructed from two questions: one on the language used at work and the other on the language used at home. Where the two coincide we assume that the employee is likely to be more skilled in the language required in the workplace. The place of education indicator is a dummy variable constructed using the age of immigration variable. Those arriving after the age at which their schooling level would normally be completed are assumed to have a foreign education. Those arriving after the minimum age of schooling but before the age at which their level of schooling would normally be completed are assumed to have a mixed education. Other respondents are assumed to have been educated in Canada (see Li, 2001).

Finally, there is the question of how to go about specifying a wage equation, given the variables that we use. With a large number of variables the precise causal sequence is always an issue. For example, almost all studies of wage determination include occupation and industry as control variables, along with human capital. But people are hired into occupations and industries on the basis of employer perceptions of their human capital. The causal sequence would then be: human capital leads to occupation and industry of employment which leads to pay. Occupation and industry of employment, in that case, are partly endogenous with respect to human capital, 
rather than simultaneous determinants of earnings. To capture that endogeneity one can imagine a more complicated modelling strategy - one that has not usually been adopted by researchers in this area.

Along similar lines, consider the effect of training. Training increases skills. Within pretty much any model of labour market functioning greater skills imply higher pay, sooner or later. However, it is clear that training is often directed to more skilled employees, who already earn more than others. There is strong evidence of this in the research on technological change. It shows that new equipment is assigned to the more skilled, so that much of the pay advantage of those using it reflects the fact that they were paid more initially rather than that their pay increased when they were assigned to, and trained to use, new equipment (Doms, Dunne, and Troske, 1997:277; Chennells and Van Reenan, 1997:596; Entorf and Kramarz, 1997:1503; DiNardo and Pischke, 1997).

One might conclude from this that a modelling strategy should be adopted that allows for endogeneity of wages with respect to training. That is not the approach we adopt for two reasons. First, we seek to specify our models in a way that makes them as similar as possible to most of those found in the existing research on the subject - that is, as reduced form equations. Second, as will be seen in our substantive discussions, we interpret our results as evidence of the characteristics of the kinds of jobs in which different IVOI categories find themselves.

Finally, the analyses presented here use the residual difference method rather than the Oaxaca-Blinder decomposition technique. There are advantages and disadvantages to both techniques (e.g., Rummery, 1992 versus Coleman, 2003). For the purposes of this paper the advantage of the residual difference method is that the effect of consecutive controls for different measures of experience shows up clearly in changes in the size of the visible minority immigrant group dummy. ${ }^{9}$

\section{Average Differences \\ Analysis}

Table 1 presents the mean differences in hourly earnings in both raw and logged form, by IVOI. To establish the comparability of our results with those of selected other researchers this table includes both women and native-born visible minority members. The broad pattern of mean differences is as follows. Within the sample of full-time, full-year employees, native-born white males earn about $\$ 1.50$ per hour more than visible minority immigrants in the full-time, full-year sample; immigrant white males earn the most - almost $\$ 2.00$ per hour more than native-born whites; and native-born visible minority members earn the least $-\$ 2.25$ per hour less than visible minority immigrants. The wage rate differences are somewhat larger in the

9. We have rerun the analysis using the Oaxaca-Blinder decomposition technique. The estimates of changes in the earnings disadvantage as a result of controls for experience are approximately the same using each method. Those results can be sent on request. 
Table 1. Mean Earnings by IVOI and Sex

\begin{tabular}{|c|c|c|c|c|c|c|c|c|c|}
\hline \multicolumn{5}{|c|}{ Full-time, Full-year Employees } & \multicolumn{5}{|c|}{ All Employees } \\
\hline Males & $\begin{array}{l}\text { Native- } \\
\text { born } \\
\text { white }\end{array}$ & $\begin{array}{l}\text { Native- } \\
\text { born } \\
\text { visible } \\
\text { minority }\end{array}$ & $\begin{array}{l}\text { Immi- } \\
\text { grant } \\
\text { white }\end{array}$ & $\begin{array}{l}\text { Immigrant } \\
\text { visible } \\
\text { minority }\end{array}$ & & $\begin{array}{l}\text { Native- } \\
\text { born } \\
\text { white }\end{array}$ & $\begin{array}{l}\text { Native- } \\
\text { born visible } \\
\text { minority }\end{array}$ & $\begin{array}{l}\text { Immi- } \\
\text { grant } \\
\text { white }\end{array}$ & $\begin{array}{l}\text { Immigrant } \\
\text { visible } \\
\text { minority }\end{array}$ \\
\hline \multicolumn{5}{|c|}{ Hourly Wages } & \multicolumn{5}{|c|}{ Hourly Wages } \\
\hline Mean & 21.17 & 17.24 & 22.94 & 19.53 & & 20.86 & 15.84 & 22.42 & 18.84 \\
\hline $\begin{array}{l}\text { mean dif- } \\
\text { ference } \\
\text { In Hourly }\end{array}$ & $\begin{array}{l}\text { (refer- } \\
\text { ence) }\end{array}$ & 0.008 & 0.015 & 0.028 & $\begin{array}{l}\text { mean dif- } \\
\text { ference } \\
\text { In Hourly }\end{array}$ & $\begin{array}{l}\text { (refer- } \\
\text { ence) } \\
\text { Wages }\end{array}$ & 0.000 & 0.012 & 0.002 \\
\hline Mean & 2.93 & 2.70 & 3.01 & 2.85 & Mean & 2.90 & 2.60 & 2.99 & 2.80 \\
\hline $\begin{array}{l}\text { P-value, } \\
\text { mean dif- } \\
\text { ference }\end{array}$ & $\begin{array}{l}\text { (refer- } \\
\text { ence) }\end{array}$ & 0.026 & 0.012 & 0.035 & $\begin{array}{l}\text { P-value, } \\
\text { mean dif- } \\
\text { ference }\end{array}$ & $\begin{array}{l}\text { (refer- } \\
\text { ence) }\end{array}$ & 0.000 & 0.001 & 0.005 \\
\hline $\mathrm{N}$ & 9141 & 150 & 1107 & 668 & & 10916 & 195 & 1275 & 769 \\
\hline Females & $\begin{array}{l}\text { Native- } \\
\text { born } \\
\text { white }\end{array}$ & $\begin{array}{l}\text { Native- } \\
\text { born } \\
\text { visible } \\
\text { minority } \\
\end{array}$ & $\begin{array}{l}\text { Immi- } \\
\text { grant } \\
\text { white }\end{array}$ & $\begin{array}{l}\text { Immigrant } \\
\text { visible } \\
\text { minority }\end{array}$ & & $\begin{array}{l}\text { Native- } \\
\text { born } \\
\text { white }\end{array}$ & $\begin{array}{l}\text { Native- } \\
\text { born visible } \\
\text { minority }\end{array}$ & $\begin{array}{l}\text { Immi- } \\
\text { grant } \\
\text { white }\end{array}$ & $\begin{array}{l}\text { Immigrant } \\
\text { visible } \\
\text { minority }\end{array}$ \\
\hline \multicolumn{5}{|c|}{ Hourly Wages } & \multicolumn{5}{|c|}{ Hourly Wages } \\
\hline Mean & 16.51 & 16.81 & 18.22 & 16.74 & Mean & 16.37 & 15.81 & 18.23 & 15.76 \\
\hline $\begin{array}{l}\text { the mean } \\
\text { difference }\end{array}$ & $\begin{array}{l}\text { (refer- } \\
\text { ence) }\end{array}$ & 0.797 & 0.023 & 0.757 & $\begin{array}{l}\text { mean dif- } \\
\text { ference }\end{array}$ & $\begin{array}{l}\text { (refer- } \\
\text { ence) }\end{array}$ & 0.655 & 0.005 & 0.336 \\
\hline \multicolumn{5}{|c|}{ In Hourly Wages } & \multicolumn{5}{|c|}{ In Hourly Wages } \\
\hline \multirow{3}{*}{$\begin{array}{l}\text { Mean } \\
\text { P-value, } \\
\text { mean dif- } \\
\text { ference } \\
\mathrm{N}\end{array}$} & 2.70 & 2.73 & 2.79 & 2.69 & \multirow{3}{*}{$\begin{array}{l}\text { Mean } \\
\text { P-value, } \\
\text { mean dif- } \\
\text { ference }\end{array}$} & 2.66 & 2.63 & 2.78 & 2.63 \\
\hline & $\begin{array}{l}\text { (refer- } \\
\text { ence) }\end{array}$ & 0.583 & 0.006 & 0.791 & & $\begin{array}{l}\text { (refer- } \\
\text { ence) }\end{array}$ & 0.534 & 0.000 & 0.390 \\
\hline & 5866 & 102 & 650 & 584 & & 8158 & 153 & 899 & 694 \\
\hline
\end{tabular}

broader, effective labour market participant, sample. The gaps between native-born whites and visible minority immigrants rises to a bit more than $\$ 2.00$ and between the two male visible minority categories to about $\$ 3.00$ per hour. The bottom half of the table shows that as compared to native-born whites visible minority women are not disadvantaged in either sample.

The overall pattern revealed in Table 1, it should be clear, is not an eccentric outcome of the WES data set. Our rankings of male earnings by IVOI coincide perfectly with those of $\mathrm{Li}$ (2000) and only differ from those of Pendakur and Pendakur (1998) in that, like Li, we find that immigrant visible minority men earn more than nativeborn visible minority men while Pendakur and Pendakur find the reverse. Our data reveal, then, a difference in earnings across the male IVOI categories that requires explanation. The difference is similar to that reported in comparable studies. ${ }^{10}$ Not

10. Divergent results might be explained by any or all of the following differences between the studies. i) The data were collected at different times from 1991 to 1999. ii) Pendakur and Pendakur, and Li exclude the Atlantic provinces, whose earnings are low and whose visible minority population is relatively small. (For confidentiality reasons, the public use sample of the Census withholds Atlantic 
surprisingly, given the narrower earnings differences between categories of women, their rankings move around more between studies. The earnings advantage of white immigrant women is consistent across studies.

In Table 2 we take a first stab at detecting bias produced by the inadequate work experience measures available from the census. Across the IVOI categories the table compares the means of the three WES experience measures, and the Mincer proxy. Again, in this table we include native-born visible minority members because they feature in other studies and there are enough of them to make possible a straightforward comparison of means.

Consider, first, the differences between the measures of cumulative work experience among males. The Mincer proxy overestimates the average experience of all relevant categories. But the overestimates are largest for visible minority immigrants. For the full-year, full-time sample the overestimate for white native men, for example, is about a year and a half on an average of 18 and a half years, for white immigrants about two years on an average of almost 22 years, and for native-born visible minority members a bit more than a year and a half on an average of about 19 years. For visible minority immigrants it is over five years on 16 years average experience. The average years of experience for the broader sample are consistently lower than for the fullyear, full-time sample, but the differences are similar, except for visible minority immigrants for whom the overestimate of experience is even larger in the full sample. ${ }^{11}$

Not surprisingly, the biasing effect of the Mincer proxy among women is even clearer. It overestimates the cumulative work experience of visible minority immigrants by about six and a half years relative to average work experience of about 14 years. Interestingly, the magnitude of the overestimate is almost as large for white immigrant women.

We can reasonably conclude that all studies using the Mincer proxy substantially overestimate visible minority work experience, relative to the much smaller overestimate of the work experience of native-born whites. Table 2 also shows that visible minority immigrants have less experience than their white counterparts on all three WES experience measures.

Canada identifiers for ethnic minorities.) This would tend to bias upwards the estimated difference in earnings between visible minority members and whites. iii) There are some differences in the composition of the IVOI categories in the Census and in WES. iv) Li included the self-employed which we and Pendakur and Pendakur do not. v) Our dependent variable is hourly earnings; that of the other two studies is total earnings. vi) Pendakur and Pendakur confine their analysis to those between 20 and 64 . We and $\mathrm{Li}$ do not impose an age restriction on our sample. vii) Our analysis rather precisely measures the hourly rate of pay while the other two studies appear to include both full-time and parttime employees. They attempt to make comparable the earnings of employees with different numbers of hours worked by adding a full-time/part-time dummy. viii) For confidentiality reasons the earnings reported by the census are truncated. This is not so for the WES data.

11. The only striking difference between the samples is that the average years of experience for visibleminority natives is much lower in the full sample than in the full-year, full-time sample. This is presumably related to the fact that many of the native-born are second generation immigrants and are therefore likely to be younger. 
Table 2. Mean Years of Experience: Different Measures

\begin{tabular}{|c|c|c|c|c|c|c|c|c|c|c|}
\hline \multicolumn{6}{|c|}{$\Longrightarrow$} & \multicolumn{5}{|c|}{ All employees } \\
\hline \multirow{2}{*}{\multicolumn{6}{|c|}{$\begin{array}{r}\text { Entire Sample } \\
\text { Cum } \\
\text { expe }\end{array}$}} & \multirow{2}{*}{\multicolumn{5}{|c|}{$\begin{array}{l}\text { Cumulative } \\
\text { experience }\end{array}$}} \\
\hline & & & & & & & & & & \\
\hline & WES & $\begin{array}{c}\text { Mincer } \\
\text { proxy }\end{array}$ & $\begin{array}{c}\text { Employer } \\
\text { duration }\end{array}$ & $\begin{array}{l}\text { Job } \\
\text { Iuration }\end{array}$ & $N$ & WES & $\begin{array}{l}\text { Mincer } \\
\text { proxy }\end{array}$ & $\begin{array}{l}\text { bloyer } \\
\text { ation }\end{array}$ & $\begin{array}{l}\text { Job } \\
\text { uration }\end{array}$ & $N$ \\
\hline All & 17.46 & 20.39 & 9.31 & 6.64 & 18268 & 16.23 & 19.80 & 8.79 & 6.46 & 23059 \\
\hline \multirow{4}{*}{$\begin{array}{l}\text { White } \\
\text { Native } \\
\text { Vis Min } \\
\text { Native } \\
\text { White Imm } \\
\text { Vis Min Imm }\end{array}$} & 17.30 & 19.82 & 9.37 & 6.60 & 15007 & 16.13 & 19.34 & 8.88 & 6.47 & 19074 \\
\hline & 16.35 & 17.58 & 6.60 & 4.59 & 252 & 11.44 & 12.52 & 5.18 & 4.04 & 348 \\
\hline & 20.42 & 24.35 & 10.34 & 7.61 & 1757 & 19.31 & 24.21 & 9.73 & 7.26 & 2174 \\
\hline & 15.41 & 21.33 & 7.81 & 6.03 & 1252 & 14.26 & 20.40 & 7.43 & 5.82 & 1463 \\
\hline \multicolumn{11}{|l|}{ Males } \\
\hline All & 18.65 & 20.66 & 9.80 & 7.11 & 11066 & 18.02 & 20.19 & 9.48 & 7.02 & 13155 \\
\hline $\begin{array}{l}\text { White } \\
\text { Native }\end{array}$ & 18.48 & 20.15 & 9.97 & 7.14 & 9141 & 17.97 & 19.80 & 9.71 & 7.12 & 10916 \\
\hline $\begin{array}{l}\text { Vis Min } \\
\text { Native }\end{array}$ & 19.35 & 20.96 & 5.82 & 4.86 & 150 & 13.81 & 14.76 & 5.04 & 4.44 & 195 \\
\hline White Imm & 21.62 & 23.80 & 10.38 & 7.70 & 1107 & 21.14 & 23.74 & 9.99 & 7.46 & 1275 \\
\hline Vis Min Imm & 16.09 & 21.42 & 7.86 & 6.30 & 668 & 15.20 & 20.75 & 7.43 & 6.00 & 769 \\
\hline \multicolumn{11}{|l|}{ Females } \\
\hline All & 16.11 & 20.09 & 8.76 & 6.10 & 7202 & 14.59 & 19.44 & 8.15 & 5.95 & 9904 \\
\hline $\begin{array}{l}\text { White } \\
\text { Native }\end{array}$ & 15.96 & 19.44 & 8.69 & 5.99 & 5866 & 14.46 & 18.93 & 8.12 & 5.89 & 8158 \\
\hline $\begin{array}{l}\text { Vis Min } \\
\text { Native }\end{array}$ & 13.31 & 14.18 & 7.38 & 4.31 & 102 & 9.12 & 10.32 & 5.32 & 3.65 & 153 \\
\hline White Imm & 18.94 & 25.02 & 10.29 & 7.50 & 650 & 17.51 & 24.67 & 9.48 & 7.06 & 899 \\
\hline Vis Min Imm & 14.70 & 21.23 & 7.76 & 5.75 & 584 & 13.41 & 20.08 & 7.43 & 5.65 & 694 \\
\hline
\end{tabular}

\section{The Base Model}

Table 3 contains two additive models - in each case with two specifications: one includes the classroom training variable, the other the (related) number of courses measure. Both include the IVOI dummies, with native-born white as the default category. The p-values (two-tail test) reported were generated from standard errors estimated using bootstrap weights provided by Statistics Canada. Model 1 contains the standard set of human capital variables, including cumulative experience. Model 2 adds to those a whole set of controls, including the location of education. The models are estimated for both the full-year, full-time and all-employee samples. The results in the table are mainly consistent with those of previous research.

Model 1, with human capital controls, shows for both samples that visible minority immigrants earn significantly less than native-born or immigrant whites. The disadvantage is larger for the all-employee sample than for the full-year, full-time sample. Earnings increase with education and experience, with the quadratic term 
Table 3. The Log Hourly Wage Rate: Additive, Males*

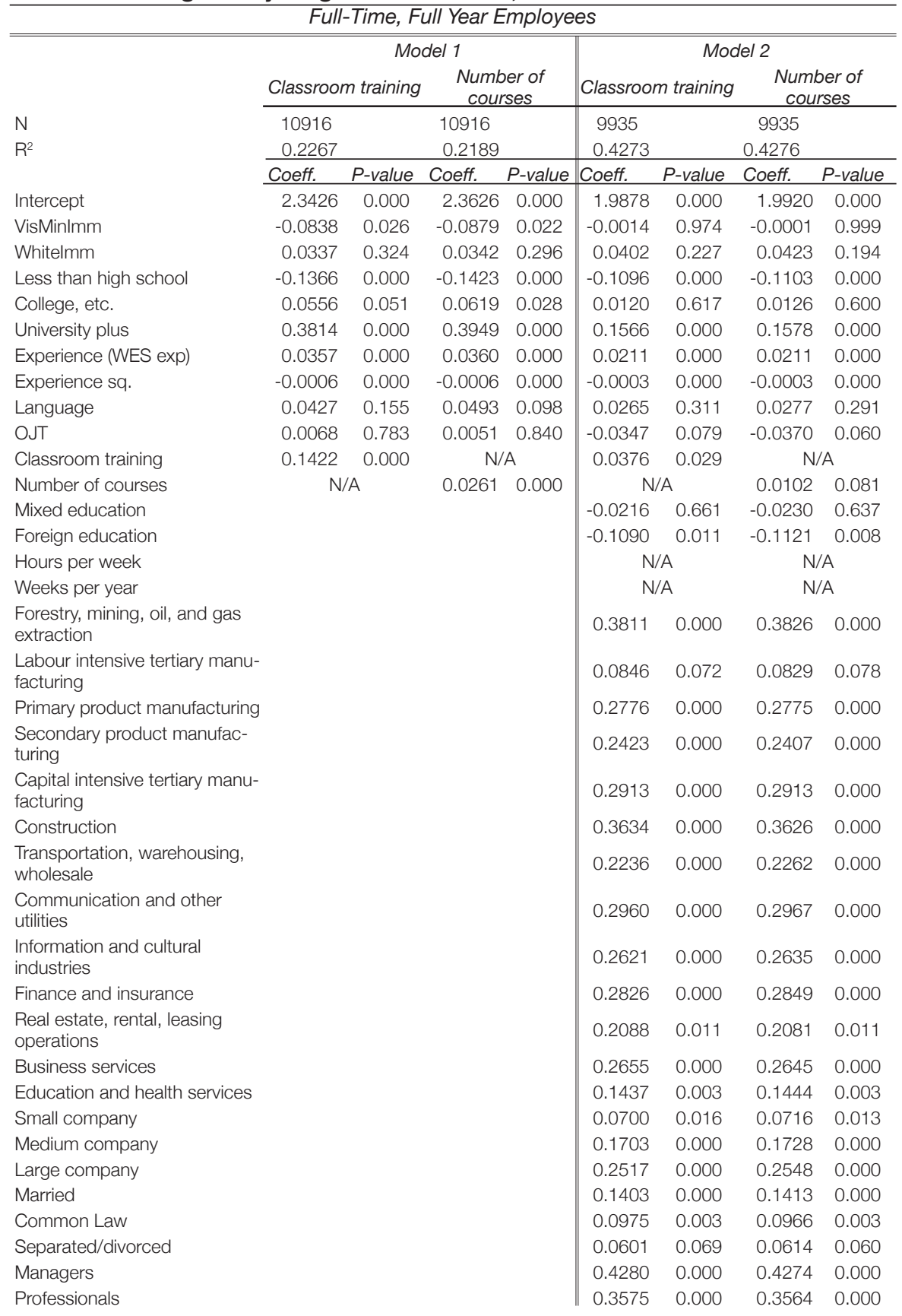


Table 3 (cont.)

\begin{tabular}{|c|c|c|c|c|c|c|c|c|}
\hline \multicolumn{9}{|c|}{ Full-time, Full Year Employees (cont.) } \\
\hline & Coeff. $\quad F$ & $P$-value & Coeff. $\quad F$ & $P$-value & Coeff. & $P$-value & Coeff. & $P$-value \\
\hline Technical/trades & & & & & 0.1484 & 0.000 & 0.1478 & 0.000 \\
\hline Sales & & & & & 0.0849 & 0.198 & 0.0835 & 0.203 \\
\hline Clerical & & & & & 0.0084 & 0.788 & 0.0071 & 0.818 \\
\hline Foreign owned & & & & & 0.0750 & 0.002 & 0.0768 & 0.001 \\
\hline Firm: incentive pay & & & & & 0.0589 & 0.001 & 0.0591 & 0.001 \\
\hline Firm: training expenses & & & & & 0.0000 & 0.006 & 0.0000 & 0.007 \\
\hline Collective bargaining & & & & & 0.0466 & 0.026 & 0.0455 & 0.031 \\
\hline Region: Quebec & & & & & -0.0639 & 0.038 & -0.0642 & 0.037 \\
\hline Region: BC & & & & & 0.0221 & 0.413 & 0.0214 & 0.426 \\
\hline Region: Other Provinces & & & & & -0.1151 & 0.000 & -0.1158 & 0.000 \\
\hline \multicolumn{9}{|l|}{${ }^{*}$ P-values for two-tailed test } \\
\hline & \multicolumn{4}{|c|}{ Model 1} & \multicolumn{4}{|c|}{ Model 2} \\
\hline & \multicolumn{2}{|c|}{$\begin{array}{l}\text { Classroom } \\
\text { training }\end{array}$} & \multicolumn{2}{|c|}{$\begin{array}{c}\text { Number of } \\
\text { courses }\end{array}$} & \multicolumn{2}{|c|}{$\begin{array}{l}\text { Classroom } \\
\text { training }\end{array}$} & \multicolumn{2}{|c|}{$\begin{array}{c}\text { Number of } \\
\text { courses }\end{array}$} \\
\hline $\mathrm{N}$ & 12960 & & 12960 & & 11859 & & 11859 & \\
\hline \multirow[t]{2}{*}{$\mathrm{R}^{2}$} & 0.2588 & & 0.2521 & & 0.4493 & & 0.4492 & \\
\hline & Coeff. & $P$-value & Coeff. & $P$-value & Coeff. & $P$-value & Coeff. & $P$-value \\
\hline Intercept & 2.3379 & 0.000 & 2.3559 & 0.000 & 2.2747 & 0.000 & 2.2777 & 0.000 \\
\hline VisMinlmm & -0.1129 & 0.001 & -0.1170 & 0.000 & -0.0450 & 0.254 & -0.0438 & 0.263 \\
\hline Whitelmm & 0.0112 & 0.689 & 0.0116 & 0.668 & 0.0049 & 0.857 & 0.0069 & 0.795 \\
\hline Less than H.S. & -0.1280 & 0.000 & -0.1335 & 0.000 & -0.1124 & 0.000 & -0.1136 & 0.000 \\
\hline College, etc. & 0.0558 & 0.028 & 0.0609 & 0.016 & 0.0046 & 0.834 & 0.0054 & 0.803 \\
\hline University plus & 0.4119 & 0.000 & 0.4247 & 0.000 & 0.1675 & 0.000 & 0.1692 & 0.000 \\
\hline Experience (WES exp) & 0.0379 & 0.000 & 0.0383 & 0.000 & 0.0208 & 0.000 & 0.0207 & 0.000 \\
\hline Experience sq. & -0.0006 & 0.000 & -0.0006 & 0.000 & -0.0003 & 0.000 & -0.0003 & 0.000 \\
\hline Language & 0.0071 & 0.814 & 0.0119 & 0.688 & 0.0011 & 0.968 & 0.0021 & 0.944 \\
\hline OJT & 0.0130 & 0.555 & 0.0101 & 0.655 & -0.0282 & 0.114 & -0.0310 & 0.082 \\
\hline Classroom training & 0.1439 & 0.000 & \multicolumn{2}{|c|}{ N/A } & 0.0550 & 0.000 & \multicolumn{2}{|c|}{ N/A } \\
\hline Number of courses & \multicolumn{2}{|c|}{ N/A } & 0.0283 & 0.000 & & $\mathrm{~N} / \mathrm{A}$ & 0.0139 & 0.018 \\
\hline Mixed education & \multicolumn{2}{|c|}{$\mathrm{N} / \mathrm{A}$} & \multicolumn{2}{|c|}{$\mathrm{N} / \mathrm{A}$} & -0.0197 & 0.638 & -0.0214 & 0.610 \\
\hline Foreign education & \multicolumn{2}{|c|}{$\mathrm{N} / \mathrm{A}$} & \multicolumn{2}{|c|}{$\mathrm{N} / \mathrm{A}$} & -0.0898 & 0.030 & -0.0938 & 0.022 \\
\hline Hours per week & \multicolumn{2}{|c|}{$\mathrm{N} / \mathrm{A}$} & \multicolumn{2}{|c|}{$\mathrm{N} / \mathrm{A}$} & -0.0052 & 0.000 & -0.0052 & 0.000 \\
\hline Weeks per year & \multirow{2}{*}{\multicolumn{2}{|c|}{$\mathrm{N} / \mathrm{A}$}} & \multicolumn{2}{|c|}{$\mathrm{N} / \mathrm{A}$} & -0.0006 & 0.610 & -0.0007 & 0.596 \\
\hline $\begin{array}{l}\text { Forestry, mining, oil, and gas } \\
\text { extraction }\end{array}$ & & & & & 0.4213 & 0.000 & 0.4236 & 0.000 \\
\hline $\begin{array}{l}\text { Labour intensive tertiary manu- } \\
\text { facturing }\end{array}$ & & & & & 0.0952 & 0.027 & 0.0937 & 0.030 \\
\hline Primary product manufacturing & & & & & 0.2851 & 0.000 & 0.2855 & 0.000 \\
\hline $\begin{array}{l}\text { Secondary product manufac- } \\
\text { turing }\end{array}$ & & & & & 0.2422 & 0.000 & 0.2413 & 0.000 \\
\hline $\begin{array}{l}\text { Capital intensive tertiary manu- } \\
\text { facturing }\end{array}$ & & & & & 0.3014 & 0.000 & 0.3024 & 0.000 \\
\hline Construction & & & & & 0.3938 & 0.000 & 0.3935 & 0.000 \\
\hline $\begin{array}{l}\text { Transportation, warehousing, } \\
\text { wholesale }\end{array}$ & & & & & 0.2370 & 0.000 & 0.2416 & 0.000 \\
\hline
\end{tabular}




\section{Table 3 (cont.)}

\begin{tabular}{|c|c|c|c|c|c|c|c|c|}
\hline \multicolumn{9}{|c|}{ All Employees (cont.) } \\
\hline & Coeff. & $P$-value & Coeff. & $P$-value & Coeff. & $P$-value & Coeff. & $P$-value \\
\hline $\begin{array}{l}\text { Communication and other } \\
\text { utilities }\end{array}$ & & & & & 0.2770 & 0.000 & 0.2790 & 0.000 \\
\hline $\begin{array}{l}\text { Information and cultural } \\
\text { industries }\end{array}$ & & & & & 0.2557 & 0.000 & 0.2579 & 0.000 \\
\hline Finance and insurance & & & & & 0.2980 & 0.000 & 0.3026 & 0.000 \\
\hline $\begin{array}{l}\text { Real estate, rental, leasing } \\
\text { operations }\end{array}$ & & & & & 0.1732 & 0.012 & 0.1734 & 0.011 \\
\hline Business services & & & & & 0.2345 & 0.000 & 0.2346 & 0.000 \\
\hline Education and health services & & & & & 0.1222 & 0.006 & 0.1239 & 0.005 \\
\hline Small company & & & & & 0.0525 & 0.038 & 0.0549 & 0.030 \\
\hline Medium company & & & & & 0.1329 & 0.000 & 0.1369 & 0.000 \\
\hline Large company & & & & & 0.2181 & 0.000 & 0.2223 & 0.000 \\
\hline Married & & & & & 0.1585 & 0.000 & 0.1601 & 0.000 \\
\hline Common Law & & & & & 0.0994 & 0.000 & 0.0987 & 0.000 \\
\hline Separated/divorced & & & & & 0.1211 & 0.002 & 0.1233 & 0.001 \\
\hline Managers & & & & & 0.4181 & 0.000 & 0.4190 & 0.000 \\
\hline Professionals & & & & & 0.3718 & 0.000 & 0.3722 & 0.000 \\
\hline Technical/trades & & & & & 0.1183 & 0.000 & 0.1189 & 0.000 \\
\hline Sales & & & & & -0.0003 & 0.992 & 0.0000 & 1.000 \\
\hline Clerical & & & & & -0.0172 & 0.617 & -0.0179 & 0.596 \\
\hline Foreign owned & & & & & 0.0562 & 0.016 & 0.0588 & 0.011 \\
\hline Firm: incentive pay & & & & & 0.0537 & 0.003 & 0.0545 & 0.002 \\
\hline Firm: training expenses & & & & & 0.0000 & 0.012 & 0.0000 & 0.011 \\
\hline Collective bargaining & & & & & 0.0619 & 0.001 & 0.0607 & 0.001 \\
\hline Region: Quebec & & & & & -0.0700 & 0.012 & -0.0703 & 0.012 \\
\hline Region: BC & & & & & 0.0429 & 0.107 & 0.0421 & 0.112 \\
\hline Region: Other Provinces & & & & & -0.1203 & 0.000 & -0.1210 & 0.000 \\
\hline
\end{tabular}

indicating the familiar reversal of the experience effect in the last years of employment. There is weak evidence that using the same language at work and home is associated with higher pay. Training in the form of employer-paid courses or classroom training at the workplace increase earnings. Interestingly, on-the-job training has no significant effect on the wage rate.

In model 2 we add controls for job and employer characteristics, and for whether or not education was completed outside Canada. The negative coefficient for visible minority immigrants falls by a lot, though by less for the all-employee sample than for full-year, full-time employees. Nonetheless, it becomes insignificant for both samples. Some of this fall is associated with the inclusion of the location of education variable. Those who completed their education outside the country - most of whom will be visible minority immigrants - get paid less as compared to those who completed it within the country. Note that, while negative, the effect of partial completion of an education outside Canada is insignificant ("Mixed education"). 
Some of the fall in the visible minority negative coefficient is also associated with the controls for job and employer characteristics. The coefficients for training shed some light on this. The magnitudes of the coefficients for classroom training and number of courses fall by more than half when industry, occupation, and employer controls are added. Evidently, industry, occupation, and other job characteristics are associated with the likelihood of being trained.

Overall, our results look like those of other researchers - though with a better experience measure the visible minority immigrant disadvantage is more fragile. Adjusting scores so that the three IVOI groups have equal amounts of human capital based on the standard sorts of measures, leaves a residual earnings disadvantage for visible minority immigrants. Part of this originates in the fact that overseas education is poorly rewarded. At the same time, training makes a difference to earnings and is evidently associated with occupation, industry, and other employer characteristics. Once these are controlled (with the better controls available in WES) the effect of visible minority immigrant status disappears. Within industries and occupations, then, visible minority immigrants are not disadvantaged. Their disadvantage originates in their differential access to jobs in industries and occupations that provide higher pay.

\section{The Effects of Experience}

Our next question is: Would our results be different had we used the Mincer proxy of work experience rather than the measure available in the WES? In Table 4 we compare relevant coefficients from equations using the two alternative measures. (Here and subsequently, only the equations containing the course training variable are included since, as we saw earlier, the course training and number of courses specifications produce similar results.) The results are what one would expect. The magnitudes of the effects of the two experience measures are about the same within each of the two models. But the size of the negative coefficient for the visible minority immigrant dummy is larger where the Mincer proxy is used than where the WES experience measure is used. In model 1, with controls for human capital, the specification within which visible minority immigrants are disadvantaged, the use of the Mincer proxy inflates the visible minority immigrant earnings disadvantage by about $30 \%$ in both samples and reduces the p-value considerably. In model 2, using the WES cumulative experience measure, the visible minority immigrant disadvantage becomes insignificant. Substituting the Mincer proxy gets the disadvantage close to significance, particularly in the all-employee sample. It is clear that the negative effect on earnings of visible minority immigrant status is overestimated in studies using census data and a Mincer proxy of experience.

As we noted earlier, in a context of substantial job loss and job creation, the cumulative experience that we examine in Table 4 may not fully capture the productivity-relevant effects of experience. There is also experience acquired working for a single employer and experience acquired in a particular job. In Table 5 we 


\section{Table 4}

\begin{tabular}{|c|c|c|c|c|c|c|c|c|}
\hline \multicolumn{9}{|c|}{ Full-Time, Full-Year Employees } \\
\hline & \multicolumn{4}{|c|}{ Model 1} & \multicolumn{4}{|c|}{ Model $2^{* *}$} \\
\hline & \multicolumn{2}{|c|}{ WES } & \multicolumn{2}{|c|}{ Mincer proxy } & \multicolumn{2}{|c|}{ WES } & \multicolumn{2}{|c|}{ Mincer proxy } \\
\hline $\mathrm{N}$ & 10916 & & 10916 & & 9935 & & 9935 & \\
\hline \multirow[t]{2}{*}{$\mathrm{R}^{2}$} & 0.2267 & & 0.2057 & & 0.4273 & & 0.4179 & \\
\hline & Coeff. & $P$-value & Coeff. & $P$-value & Coeff. & $P$-value & Coeff. & $P$-value \\
\hline VisMinlmm & -0.0838 & 0.026 & -0.1192 & 0.001 & -0.0014 & 0.974 & -0.0182 & 0.668 \\
\hline Whitelmm & 0.0337 & 0.324 & 0.0287 & 0.394 & 0.0402 & 0.227 & 0.0423 & 0.185 \\
\hline Experience & 0.0357 & 0.000 & 0.0354 & 0.000 & 0.0211 & 0.000 & 0.0187 & 0.000 \\
\hline $\begin{array}{l}\text { Experience } \\
\text { squared }\end{array}$ & -0.0006 & 0.000 & -0.0006 & 0.000 & -0.0003 & 0.000 & -0.0003 & 0.000 \\
\hline \multicolumn{9}{|c|}{ All Employees } \\
\hline & \multicolumn{4}{|c|}{ Model 1} & \multicolumn{4}{|c|}{ Model $2^{* *}$} \\
\hline & \multicolumn{2}{|c|}{ WES } & \multicolumn{2}{|c|}{ Mincer proxy } & \multicolumn{2}{|c|}{ WES } & \multicolumn{2}{|c|}{ Mincer proxy } \\
\hline N & 12960 & & 12960 & & 11859 & & 11859 & \\
\hline \multirow[t]{2}{*}{$\mathrm{R}^{2}$} & 0.2588 & & 0.2417 & & 0.4493 & & 0.4411 & \\
\hline & Coeff. & P-value & Coeff. & $P$-value & Coeff. & $P$-value & Coeff. & P-value \\
\hline VisMinlmm & -0.1129 & 0.001 & -0.1606 & 0.000 & -0.0450 & 0.254 & -0.0663 & 0.101 \\
\hline Whitelmm & 0.0112 & 0.689 & 0.0009 & 0.975 & 0.0049 & 0.857 & 0.0072 & 0.787 \\
\hline Experience & 0.0379 & 0.000 & 0.0385 & 0.000 & 0.0208 & 0.000 & 0.0196 & 0.000 \\
\hline $\begin{array}{l}\text { Experience } \\
\text { squared }\end{array}$ & -0.0006 & 0.000 & -0.0006 & 0.000 & -0.0003 & 0.000 & -0.0003 & 0.000 \\
\hline
\end{tabular}

separately add measures of those forms of experience to the cumulative experience measure. Only the results for model 1 are presented. We saw earlier that introducing controls for industry and job into the additive model eliminated the significant earnings disadvantage of visible minority immigrants. In addition, the quadratic terms for duration in job and with employer are insignificant. We have omitted those terms from the final equation.

Three initial results stand out. The first is that, when duration of employment with current employer is added to an equation containing cumulative experience, the coefficients for the two cumulative experience terms are only slightly changed. This is true for both samples. Second, the linear term for duration of employment with current employer is separately positive and significant. Third, duration in current job also has a separate positive effect on earnings. Note, furthermore, that we have explored the extent of multicollinearity in the equation - beyond the relative stability of the cumulative experience coefficients across specifications. The variance inflation factors are low. ${ }^{12}$ The results in the combined cumulative experience and duration with employer equations seem to reflect genuine independent effects. With similar levels of cumulative experience, those with a longer duration with the current

12. In models without the quadratic terms all the variance inflation factors fall within the range of 1 to about 1.75. When the quadratic terms are added the factor for cumulative experience increases to a little over 10 , while the other factors remains in the 1 to 1.75 range. 
Table 5. Log Hourly Wage Rate with Employment and Job Duration*

\begin{tabular}{|c|c|c|c|c|}
\hline \multicolumn{5}{|c|}{ Full-Time, Full-Year } \\
\hline & \multicolumn{2}{|c|}{ Employment duration } & \multicolumn{2}{|c|}{ Job duration } \\
\hline$N$ & 10916 & & 10916 & \\
\hline \multirow[t]{2}{*}{$R^{2}$} & 0.2457 & & 0.2285 & \\
\hline & Coeff. & $P$-value & Coeff. & $P$-value \\
\hline Intercept & 2.3213 & 0.000 & 2.3320 & 0.000 \\
\hline VisMinlmm & -0.0734 & 0.035 & -0.0834 & 0.025 \\
\hline Whitelmm & 0.0433 & 0.194 & 0.0353 & 0.296 \\
\hline Less than H.S. & -0.1425 & 0.000 & -0.1385 & 0.000 \\
\hline College, etc. & 0.0592 & 0.034 & 0.0565 & 0.048 \\
\hline University plus & 0.3879 & 0.000 & 0.3852 & 0.000 \\
\hline Experience (WES exp) & 0.0315 & 0.000 & 0.0350 & 0.000 \\
\hline Experience sq. & -0.0006 & 0.000 & -0.0006 & 0.000 \\
\hline Duration & 0.0091 & 0.000 & 0.0033 & 0.010 \\
\hline Language & 0.0476 & 0.099 & 0.0438 & 0.146 \\
\hline OJT & 0.0110 & 0.655 & 0.0103 & 0.675 \\
\hline Classroom training & 0.1383 & 0.000 & 0.1441 & 0.000 \\
\hline \multicolumn{5}{|c|}{ All Employees } \\
\hline & \multicolumn{2}{|c|}{ Employment duration } & \multicolumn{2}{|c|}{ Job duration } \\
\hline $\mathrm{N}$ & 12960 & & 12960 & \\
\hline \multirow[t]{2}{*}{$\mathrm{R}^{2}$} & 0.2815 & & 0.2648 & \\
\hline & Coeff. & $P$-value & Coeff. & $P$-value \\
\hline Intercept & 2.3123 & 0.000 & 2.3201 & 0.000 \\
\hline VisMinlmm & -0.1014 & 0.001 & -0.1113 & 0.001 \\
\hline Whitelmm & 0.0218 & 0.418 & 0.0148 & 0.587 \\
\hline Less than H.S. & -0.1361 & 0.000 & -0.1318 & 0.000 \\
\hline College, etc. & 0.0593 & 0.017 & 0.0568 & 0.026 \\
\hline University plus & 0.4185 & 0.000 & 0.4174 & 0.000 \\
\hline Experience (WES exp) & 0.0334 & 0.000 & 0.0365 & 0.000 \\
\hline Experience sq. & -0.0006 & 0.000 & -0.0006 & 0.000 \\
\hline Duration & 0.0103 & 0.000 & 0.0060 & 0.000 \\
\hline Language & 0.0102 & 0.727 & 0.0079 & 0.794 \\
\hline OJT & 0.0185 & 0.398 & 0.0192 & 0.376 \\
\hline Classroom training & 0.1387 & 0.000 & 0.1470 & 0.000 \\
\hline
\end{tabular}

${ }^{*}$ P-values for two-tailed test

employer get paid more.

Another interesting result is that the addition to the equation of duration with current employer slightly weakens the pay disadvantage of visible minority immigrants in both samples - by a bit more than $10 \%$, in fact. Generally speaking, our results suggest that the three forms of experience have separate effects on earnings, and play some role in explaining the earnings disadvantage of visible minority immigrants. 


\section{Discussion}

Analyses using the public use sample of the census can luxuriate (so to speak) in very large sample sizes - up to 350,000 cases for those using the 1996 version. Using the WES, we do not have that advantage. Still, we do have a respectable 10,000 or so cases. In addition, as compared to the census, we have unambiguously superior information with respect to work experience and work characteristics. More recently, the SLID has been used in analyses of the earnings disadvantage of visible minority immigrants. There are also some advantages to the WES as compared to the SLID. The WES has superior information on work characteristics, its measure of work experience may be better, and it also includes information on training, a critical component of work experience, in our view.

With these data, across the two samples, we have shown the following.

- Like other studies, our analysis of WES data indicates that visible minority men get paid less than their white counterparts - whether immigrant or nativeborn.

- The Mincer proxy overestimates the work experience of visible minority immigrants by more than it overestimates that of immigrant or native-born whites.

- The magnitude of the estimated negative effect on earnings of visible minority immigrant status is increased when the Mincer proxy of experience is used rather than the WES measure.

- Training, measured as classroom training or number of courses, is associated with higher pay.

- After controlling for human capital, including training experience, visible minority immigrants remain disadvantaged, though only modestly so.

- Adding (better measured) controls for industry, occupation, and job removes the earnings disadvantage of visible minority immigrants entirely. Doing so also reduces the training effect on pay.

- Different kinds of experience - cumulative, duration with employer, and duration in job - have separate effects on pay and modify the relation between visible minority immigrant status and pay.

What is to be made of all this?

First, and most fundamentally, we have shown that poor measurement of work experience leads to an overestimate of visible minority immigrant earnings disadvantage. This is not just a question of the dependence on the Mincer proxy in the bulk of the research - though that is certainly important. More generally, research using either the residual difference or the Oaxaca-Blinder decomposition method, the logic of which require careful measurement of human capital, has settled for an unsuitably simplified model of the relation between work experience and productivity. Cumulative work experience, even if properly measured, does not deal with the fact that employer- and job-specific skills will often be lost when an immigrant changes 
countries and jobs; nor does it take into account the connection between employerprovided training and productivity and the fact that language difficulties are likely to reduce the incidence of training among immigrants.

Second, remember that the effect of training on earnings in model 1 was reduced when industry and related measures were added in model 2 . This suggests that the separation of human capital from other effects, a separation that is crucial to the logic of the methods we consider here, is problematic. Occupation, industry, and other employer traits are treated as separate and distinct from human capital. But employers vary in the extent to which they provide training. Unless there is a direct measure of training incidence - of the sort available in the data set used here - it is likely that differences in the amount of human capital acquired through training are likely to be embedded in the industry and related controls.

We would push this point a little further. Our measures of training only tell us about what happened to the respondents in the previous year. We do not have evidence on cumulative training, which is unlikely to fully coincide with cumulative experience. Both a short-order cook and, say, a patent agent may have twenty years of cumulative work experience, possibly with the same employer. We would argue that they are very unlikely to have received equivalent amounts of employer-provided training. Our analysis probably underestimates the effect of training on earnings. It is possible that the visible minority immigrant coefficient would be modified by better cumulative training information. Our guess is that it is more likely to reduce the negative effect of visible minority immigrant status than to increase it. But that is a matter for further research.

This leads to the next point. There is no perfect data set, and this is true of the one we have used here. We would underline four of its weaknesses. First, we do not have a complete set of pertinent measures of education. We know from Ferrer and Riddell (2002) that, in addition to level of education, field of study makes a difference to earnings. Second, there is no measure of field of study in the WES. Nor do we have a measure of community size. But earnings are related to community size and immigrants are concentrated in large communities, so our estimate of their earnings disadvantage is biased downwards. Third, in this analysis we have treated visible minority immigrant status as a homogeneous category. As discussed earlier, we know from the analysis of census data by Pendakur and Pendakur (2002) that there have been substantial differences in the earnings of native-born visible minority members with different ethnic origins. It is likely that there are similar differences among the foreign born. Our sample size, however, is not sufficiently large to allow an exploration of that. Finally, as noted earlier, the smaller sample size of the WES means that coefficients that would be significant with the census may be insignificant with the WES.

However, in addition to the problem with the measurement of experience emphasized throughout this paper there are further problems with the previous research reviewed earlier. Despite the fact that the census provides information on field of 
study, none of the papers discussed earlier uses that information in the models estimated. Similarly, while the public use sample of the census provides a large enough sample to explore differences among ethnic groups in wage outcomes, the research cited earlier largely fails to exploit that possibility. Furthermore, while papers using the census do include community size variables they exclude Atlantic Canada. The public use sample of the census withholds visible minority identifiers for Atlantic Canada for confidentiality reasons. This means that the estimates of disadvantage in those studies are biased upwards because a good sized native-born population with generally low wages is excluded from their data. There is no reason to think that the inflation of the estimate of the magnitude of disadvantage caused by the absence of Atlantic Canada in research that uses the census precisely offsets the reduction in the estimate caused by the absence of a measure of community size in our research. We would simply underline the fact that there are difficulties with the estimates from existing research.

\section{Conclusion}

The fact remains that our results indicate that visible minority immigrant men earn less than whites after controls for human capital. This disadvantage rests, substantially, on the depreciation of education completed overseas. Many visible minority immigrants are channelled into jobs that are less likely to match their level of certification than is the case for the other two IVOI categories. This disadvantage could be construed as discrimination.

The issue, however, is not straightforward. Consider these perceptive remarks by Reitz (2001:372-373) on the issue of the evaluation of overseas educational credentials.

Foreign applicants to Canadian graduate programs present undergraduate credentials from around the world. The capacity of these Canadian graduate programs to evaluate many of the degrees from Asian, African, and Latin American universities is actually quite poor. Few within Canadian universities know more than a few of these foreign universities well, and programs are forced to rely on ratings systems which are quite crude... If universities who specialize in credentials have problems, it is not hard to imagine that employers would also have problems. Universities might be justified in being credential-conservative - tending toward negative decisions in the absence of definite knowledge, in order to protect academic standards. But the consequences of a wrong decision are not great. After all, university programs with foreign applicants are considering students essentially as customers, not as employees. It is employers who have more to lose from hiring a foreign worker who turns out to be unproductive.

Reitz's point is that the problems in evaluating credentials confronted by university teachers are equally confronted by private sector employers, for whom the costs of a recruitment error are, he plausibly argues, probably higher. All this is to say that the assignment to discrimination of the place of education effect may have 
been unsatisfactorily facile.

For some employers hiring errors imply high costs - particularly where the employer invests substantially in training (Barron, Berger, and Black (1997:186). Given this, employers offering higher-paying jobs - jobs that are more likely to involve training - are likely to act cautiously where they are uncertain of the value of a credential - say, a high school diploma from a third world country. They may require evidence of satisfactory previous work performance in jobs offering lower pay and/or may hire into effectively probationary job statuses of varying durations. Language skills - beyond the census-elicited information on whether the respondent can hold a conversation in an official language - are likely to matter in most well-paid jobs. If the much discussed "knowledge economy" means anything it is surely that (Rubenson and Schuetze, 2000; Stehr, 2002). ${ }^{13} \mathrm{We}$ do, as a matter of fact, have good evidence that employers are good at screening job candidates whose cognitive skills, including language mastery, do not match their certification (Pryor and Schaffer, 1997; Boothby, 1999:37-40). This screening process might be expected to be of particular relevance in the hiring of someone with a difficult-to-interpret educational diploma.

All this being said, we certainly do not claim that the evidence assembled here demonstrates the absence of discrimination. Nor do our results contradict those that demonstrate a decline in the labour market performance of recent as compared to previous immigrants. In fact, falling returns to experience appear to provide a substantial part of the explanation for that relative decline (e.g., Picot and Sweetman, 2005:22). Our exploration of the effect of visible minority immigrant experience on earnings complements this finding. More generally, while not suggesting that discrimination does not exist our results do raise some questions about the magnitude of discrimination that has been inferred from previous studies.

\section{Acknowledgements}

This research was funded by the Canadian government department formerly known as Human Resources Development Canada. We are indebted to the staff of the Centre interuniversitaire québécois de statistiques sociales and to comments on an earlier version of this paper from Axel van den Berg, Morton Weinfeld, and this journal's anonymous reviewers.

13. In comparing the employment outcomes of current immigrants with previous ones the requirements of the knowledge economy are a major consideration. Earlier waves of immigrants came to a Canada that provided large numbers of jobs in manufacturing and mining - jobs that required only modest English or French literacy. In fact, the trade skills they had acquired in their countries of origin were often highly valued on the Canadian labour market, which did not provide comparable trades training (e.g., Meltz, 1982:7). The share of jobs in manufacturing and mining has since fallen dramatically, to be replaced by jobs in the service sector that do require language skills. Recent waves of immigrants, who are disproportionately members of visible minorities, may have official language skills equal to those of the Ukrainians, Greeks, Italians, Portuguese, and others who preceded them. But in the largely white-collar "knowledge economy" the absence of those skills matters much more. 


\section{References}

Adamuti-Trache, M. and R. Sweet. 2005. "Exploring the relationship between educational credentials and the earnings of immigrants." Canadian Studies in Population 32:177-201.

Baldwin, John, Timothy Dunne, and John Haltiwanger. 1998. "A comparison of job creation and job destruction in Canada and the United States." The Review of Economics and Statistics 80:347-356.

Barron, J.M., M.C. Berger, and D.A. Black. 1997. On-the-Job Training. Kalamazoo, MI: W.E. Upjohn Institute.

Becker, G.S. 1975. Human Capital: A Theoretical and Empirical Analysis with Special Reference to Education (2nd ed.). Chicago: University of Chicago Press.

Boothby, D. 1999. Literacy Skills, the Knowledge Content of Occupations and Occupational Mismatch. Ottawa: Applied Research Branch, Human Resources Development Canada, W99-3E.

Boyd, M. and D. Thomas. 2002. "Skilled immigrant labour: Country of origin and the occupational locations of male engineers." Canadian Studies in Population 29:71-99.

Chennells, L. and J. Van Reenan. 1997. "Technical change and earnings in British establishments." Economica 64:587-604.

Christofides, L.N. and R. Swidinsky. 1994. "Wage determination by gender and visible minority status: Evidence from the 1989 LMAS." Canadian Public Policy 20:34-51.

Coleman, M.G. 2003. “Job skill and black male wage discrimination.” Social Science Quarterly 84:892905.

Davies, Scott, Clayton Mosher and Bill O'Grady. 1996. "Educating women: Gender inequalities among Canadian university graduates." The Canadian Review of Sociology and Anthropology 33:125142 .

de Silva, A. 1992. Earnings of Immigrants: A Comparative Analysis. Ottawa: Economic Council of Canada.

- 1997. "Wage discrimination against visible minority men in Canada." Canadian Business Economics 5:25-42.

DiNardo, J.E. and J.-S. Pischke. 1997. "The returns to computers revisited: Have pencils changed the wage structure too?" Quarterly Journal of Economics 112:291-303.

Doms, M, T. Dunne, and K. Troske. 1997. "Workers, wages, and technology." Quarterly Journal of Economics 112:253-290.

Drolet, M. 2002. The "Who, What, When and Where" of Gender Pay Differentials. Ottawa: Statistics Canada and Human Resources Development Canada.

Duncan, G.J. and S. Hoffman. 1979. "On-the-job training and earnings differences by race and sex." Review of Economics and Statistics 61:594-603.

Entorf, H. and F. Kramarz. 1997. "Does unmeasured ability explain the higher wages of new technology workers?" European Economic Review 41:1489-1509.

Ferrer, A.M. and W.C. Riddell. 2002. "The role of credentials in the Canadian labour market." Canadian Journal of Economics 35:879-905.

Heckman, J.J. 2004. “Detecting discrimination.” Journal of Economic Perspectives 12:101-116. 
Hum, D. and W. Simpson. 1999. "Wage opportunities for visible minorities in Canada." Canadian Public Policy 25:379-394.

2003. "Job-related training activity by immigrants to Canada." Canadian Public Policy 29:469490.

2004. "Reinterpreting the performance of immigrant wages from panel data." Empirical Economics 29:129-147.

Kidd, M.P. and M. Shannon. 1997. "Imputation of female labour market experience: Some Australian evidence on the Zabalza and Arrufat method." Economic Record 73:136-145.

Klein, Michael W., Scott Schuh, and Robert K. Triest. 2003. "job creation, job destruction, and the real exchange rate." Journal of International Economics 59:239-265.

Li, P.S. 2000 "Earnings disparities between immigrants and native-born Canadians." Canadian Review of Sociology and Anthropology 37:289-311.

2001. "The market worth of immigrants educational credentials." Canadian Public Policy 27:2338.

Meltz, N.M. 1982. Economic Analysis of Labour Shortages: The Case of Tool and Die Makers in Ontario. Toronto: Ontario Economic Council.

Pendakur, K. and R. Pendakur. 2002. "Colour my world: Have earnings gaps for Canadian-born ethnic minorities changed over time?" Canadian Public Policy 28:489-512.

1998. "The colour of money: Earnings differentials among ethnic groups in Canada." Canadian Journal of Economics 31:518-548.

Picot, G. and A. Sweetman. 2005. "The deteriorating economic welfare of immigrants and possible causes: Update 2005.” Analytical Studies Research Paper Series No. 262. Ottawa: Statistics Canada.

Pryor, F.L. and D.L. Schaffer. 1997. "Wages and the university educated: A paradox resolved." Monthly Labor Review 120 (July) 3-14.

Reitz, J.G. 1998. The Warmth of the Welcome: The Social Causes of Economic Success for Immigrants in Different Nations and Cities. Boulder, CO: Westview Press.

2001. "Immigrant skill utilization in the Canadian labour market: Implications of human capital research." Journal of International Migration and Integration 2:347-378.

Renaud, J. et T. Cayn. 2006. Un emploi correspondant à ses compétences? Les travailleurs sélectionnés et l'accès à un emploi qualifié au Québec. Québec: Gouvernement du Québec.

Rubenson, K. and H.G. Schuetze, eds., 2000. Transition to the Knowledge Society: Policies and Strategies for Individual Participation and Learning. Vancouver, B.C.: UBC Institute for European Studies.

Rummery, S. 1992. "The contribution of intermittent labour force participation to the gender wage differential.” Economic Record 68:351-364.

Stehr, N. 2002. Knowledge and Economic Conduct: The Social Foundations of the Knowledge Economy. Toronto: University of Toronto Press.

Swidinsky, R. and M. Swidinsky. 2002. "The relative earnings of visible minorities in Canada: New evidence from the 1996 Census." Relations industrielles 57:630-659.

Wanner, R.A. 1998. "Prejudice, profit, or productivity: Explaining returns to human capital among male immigrants to Canada." Canadian Ethnic Studies 30:24-55.

- 2003. "Entry class and the earnings of immigrants to Canada, 1980-1995." Canadian Public Policy 29:53-71. 
Yoshida, Y. and M.R. Smith. 2005. "Training and the earnings of immigrant males: Evidence from the Canadian Workplace and Employee Survey.” Social Science Quarterly 86: 1218-1241. 


\section{Appendix: Description of Variables*}

\begin{tabular}{|c|c|c|c|c|c|c|c|}
\hline \multirow[b]{2}{*}{ Variable } & \multirow[b]{2}{*}{$\begin{array}{l}\text { Description/ } \\
\text { categories }\end{array}$} & \multicolumn{3}{|c|}{ Male Full-time Full-year workers } & \multicolumn{3}{|c|}{ Male all workers } \\
\hline & & $\begin{array}{l}\text { Native- } \\
\text { born } \\
\text { white }\end{array}$ & $\begin{array}{c}\text { Immigrant } \\
\text { white }\end{array}$ & $\begin{array}{l}\text { Immigrant } \\
\text { visible } \\
\text { minority }\end{array}$ & $\begin{array}{l}\text { Native- } \\
\text { born } \\
\text { white }\end{array}$ & $\begin{array}{l}\text { Immi- } \\
\text { grant } \\
\text { white }\end{array}$ & $\begin{array}{l}\text { Immigrant } \\
\text { visible } \\
\text { minority }\end{array}$ \\
\hline \multirow{4}{*}{ Education } & Less than high school & $12.65 \%$ & $9.17 \%$ & $10.91 \%$ & $13.94 \%$ & $9.43 \%$ & $10.53 \%$ \\
\hline & High school (ref) & $21.75 \%$ & $16.21 \%$ & $14.74 \%$ & $20.84 \%$ & $16.87 \%$ & $14.91 \%$ \\
\hline & Some postsecondary & $47.97 \%$ & $49.11 \%$ & $36.98 \%$ & $47.71 \%$ & $46.28 \%$ & $39.37 \%$ \\
\hline & University or above & $17.64 \%$ & $25.51 \%$ & $37.37 \%$ & $17.51 \%$ & $27.42 \%$ & $35.19 \%$ \\
\hline \multirow{2}{*}{ Language } & $\begin{array}{l}\text { Different at work and } \\
\text { at home }\end{array}$ & $4.46 \%$ & $29.42 \%$ & $45.81 \%$ & $95.40 \%$ & $72.53 \%$ & $54.16 \%$ \\
\hline & $\begin{array}{l}\text { Same at work and at } \\
\text { home }\end{array}$ & $95.54 \%$ & $70.58 \%$ & $54.19 \%$ & $4.60 \%$ & $27.47 \%$ & $45.84 \%$ \\
\hline \multirow{2}{*}{ OJT } & $\begin{array}{l}\text { No on-the-job training } \\
\text { received }\end{array}$ & $70.86 \%$ & $77.18 \%$ & $73.82 \%$ & $71.36 \%$ & $77.28 \%$ & $74.06 \%$ \\
\hline & $\begin{array}{l}\text { On-the-job training } \\
\text { received }\end{array}$ & $29.14 \%$ & $22.82 \%$ & $26.18 \%$ & $28.64 \%$ & $22.72 \%$ & $25.94 \%$ \\
\hline \multirow{3}{*}{$\begin{array}{l}\text { Classroom } \\
\text { training }\end{array}$} & None & $60.34 \%$ & $64.40 \%$ & $67.53 \%$ & $62.87 \%$ & $65.67 \%$ & $69.66 \%$ \\
\hline & Some & $39.66 \%$ & $35.60 \%$ & $32.47 \%$ & $37.13 \%$ & $34.33 \%$ & $30.34 \%$ \\
\hline & Durses & 0.97 & 0.76 & 0.75 & || 0.89 & 0.72 & 0.68 \\
\hline \multirow{8}{*}{$\begin{array}{l}\text { Place of } \\
\text { educa- } \\
\text { tion** }\end{array}$} & In Canada (ref) & $100 \%$ & $36.26 \%$ & $12.30 \%$ & $100 \%$ & $37.63 \%$ & $14.89 \%$ \\
\hline & Mixed & 0 & $28.39 \%$ & $38.64 \%$ & $0 \%$ & $28.52 \%$ & $36.62 \%$ \\
\hline & $\begin{array}{l}\text { Outside of Canada } \\
\text { Forestry, mining, oil, }\end{array}$ & 0 & $35.34 \%$ & $49.06 \%$ & $0 \%$ & $33.85 \%$ & $48.49 \%$ \\
\hline & $\begin{array}{l}\text { and gas extraction } \\
\text { Primary product } \\
\text { manufacturing }\end{array}$ & $10.15 \%$ & $6.23 \%$ & $5.31 \%$ & $10.04 \%$ & $5.80 \%$ & $5.38 \%$ \\
\hline & $\begin{array}{l}\text { Labour intensive ter- } \\
\text { tiary manufacturing }\end{array}$ & $5.53 \%$ & $7.87 \%$ & $9.60 \%$ & $5.02 \%$ & $6.97 \%$ & $8.42 \%$ \\
\hline & $\begin{array}{l}\text { Secondary product } \\
\text { manufacturing }\end{array}$ & $5.18 \%$ & $6.26 \%$ & $5.74 \%$ & $4.62 \%$ & $5.95 \%$ & $5.21 \%$ \\
\hline & $\begin{array}{l}\text { Capital intensive ter- } \\
\text { tiary manufacturing }\end{array}$ & $8.68 \%$ & $13.08 \%$ & $9.39 \%$ & $7.85 \%$ & $11.81 \%$ & $9.31 \%$ \\
\hline & Construction & $6.29 \%$ & $7.40 \%$ & $1.14 \%$ & $6.67 \%$ & $7.98 \%$ & $1.37 \%$ \\
\hline \multirow{8}{*}{ Industry*** } & $\begin{array}{l}\text { Transportation, ware- } \\
\text { housing, wholesale }\end{array}$ & $16.31 \%$ & $12.61 \%$ & $11.27 \%$ & $15.13 \%$ & $11.79 \%$ & $10.10 \%$ \\
\hline & $\begin{array}{l}\text { Communication and } \\
\text { other utilities }\end{array}$ & $3.66 \%$ & $1.87 \%$ & $1.53 \%$ & $3.18 \%$ & $1.62 \%$ & $1.89 \%$ \\
\hline & $\begin{array}{l}\text { Retail trade and con- } \\
\text { sumer services (ref) }\end{array}$ & $17.37 \%$ & $11.08 \%$ & $23.77 \%$ & $19.33 \%$ & $12.43 \%$ & $26.63 \%$ \\
\hline & Finance and insurance & $2.86 \%$ & $3.16 \%$ & $6.61 \%$ & $2.61 \%$ & $2.86 \%$ & $5.65 \%$ \\
\hline & $\begin{array}{l}\text { Real estate, rental and } \\
\text { leasing operations }\end{array}$ & $1.57 \%$ & $1.80 \%$ & $2.11 \%$ & $1.78 \%$ & $1.59 \%$ & $2.05 \%$ \\
\hline & Business services & $8.62 \%$ & $14.16 \%$ & $15.43 \%$ & $8.18 \%$ & $14.60 \%$ & $14.93 \%$ \\
\hline & $\begin{array}{l}\text { Education and health } \\
\text { services }\end{array}$ & $9.81 \%$ & $10.01 \%$ & $6.61 \%$ & $11.91 \%$ & $12.29 \%$ & $7.61 \%$ \\
\hline & $\begin{array}{l}\text { Information and cul- } \\
\text { tural industries }\end{array}$ & $3.97 \%$ & $4.48 \%$ & $1.50 \%$ & $3.69 \%$ & $4.32 \%$ & $1.45 \%$ \\
\hline \multirow{3}{*}{$\begin{array}{l}\text { Number } \\
\text { employees }\end{array}$} & $<20$ (ref) & $28.11 \%$ & $28.45 \%$ & $30.78 \%$ & $28.65 \%$ & $27.74 \%$ & $33.92 \%$ \\
\hline & 20 to 99 & $30.65 \%$ & $25.74 \%$ & $30.70 \%$ & $31.29 \%$ & $27.13 \%$ & $28.83 \%$ \\
\hline & $100-499$ & $20.28 \%$ & $23.62 \%$ & $24.46 \%$ & $19.34 \%$ & $22.27 \%$ & $23.53 \%$ \\
\hline
\end{tabular}




\section{Appendix (cont.)}

\begin{tabular}{|c|c|c|c|c|c|c|c|}
\hline \multirow[b]{2}{*}{ Variable } & \multirow[b]{2}{*}{$\begin{array}{l}\text { Description/ } \\
\text { categories }\end{array}$} & \multicolumn{3}{|c|}{ Male Full-time Full-year workers } & \multicolumn{3}{|c|}{ Male all workers } \\
\hline & & $\begin{array}{c}\text { Native- } \\
\text { born } \\
\text { white }\end{array}$ & $\begin{array}{c}\text { Immigrant } \\
\text { white }\end{array}$ & $\begin{array}{c}\text { Immigrant } \\
\text { visible } \\
\text { minority }\end{array}$ & \begin{tabular}{|c|} 
Native- \\
born \\
white
\end{tabular} & $\begin{array}{c}\text { Immi- } \\
\text { grant } \\
\text { white }\end{array}$ & $\begin{array}{c}\text { Immigrant } \\
\text { visible } \\
\text { minority }\end{array}$ \\
\hline \multirow{4}{*}{$\begin{array}{l}\text { Marital } \\
\text { status }\end{array}$} & $\begin{array}{l}\text { Single never married } \\
\text { (ref) }\end{array}$ & $18.61 \%$ & $11.37 \%$ & $20.44 \%$ & $21.46 \%$ & $13.23 \%$ & $22.48 \%$ \\
\hline & Legally married & $60.33 \%$ & $74.42 \%$ & $72.69 \%$ & $57.63 \%$ & $71.78 \%$ & $70.51 \%$ \\
\hline & & & & & $14.51 \%$ & & \\
\hline & $\begin{array}{l}\text { Sepa } \\
\text { wido }\end{array}$ & $6.58 \%$ & $6.67 \%$ & $5.08 \%$ & $6.40 \%$ & $6.57 \%$ & $4.33 \%$ \\
\hline \multirow{5}{*}{$\begin{array}{l}\text { Occupa- } \\
\text { tion }\end{array}$} & & & & & & & \\
\hline & Profe & & & & & & 19. \\
\hline & Techn & $\%$ & 44.0 & 39.1 & $50.2 \varepsilon$ & $43.10 \%$ & $39.81 \%$ \\
\hline & Mark & & & & $2.78 \%$ & $5.35 \%$ & $6.27 \%$ \\
\hline & & 6.81 & & & $6.52 \%$ & $2.85 \%$ & $9.34 \%$ \\
\hline & Foreig & $89.12 \%$ & 88.8 & 89.63 & $90.14 \%$ & $89.55 \%$ & $89.95 \%$ \\
\hline & Foreic & & & & $9.86 \%$ & $10.45 \%$ & $10.05 \%$ \\
\hline Incentive & Not p & $54.56 \%$ & 49.4 & 47.8 & $58.03 \%$ & $50.37 \%$ & $49.48 \%$ \\
\hline \multirow{2}{*}{$\begin{array}{c}\text { pay } \\
\text { Training } \\
\text { expenses }\end{array}$} & Present & $45.44 \%$ & $50.51 \%$ & $52.15 \%$ & $41.97 \%$ & $49.63 \%$ & $50.52 \%$ \\
\hline & \$ per employee & 373.48 & 272.96 & 204.26 & $\beta 46.29$ & 262.12 & 200.93 \\
\hline \multirow{2}{*}{$\begin{array}{l}\text { Collective } \\
\text { bargaining }\end{array}$} & $\begin{array}{l}\text { No collec } \\
\text { agreemel }\end{array}$ & $70.23 \%$ & $75.12 \%$ & $83.71 \%$ & $69.38 \%$ & $73.81 \%$ & $83.09 \%$ \\
\hline & Collective agreement & $29.77 \%$ & $24.88 \%$ & $16.29 \%$ & $30.62 \%$ & $26.19 \%$ & $16.91 \%$ \\
\hline
\end{tabular}

*'Ref' is reference category in polytomous dummy variable analysis.

**Place of education based on age at immigration: 'In Canada' if less than 15; 'Mixed' if between 13 and 24; 'Outside Canada" if over 25

${ }^{\star \star \star}$ Forestry, mining, oil and gas extraction and Primary product manufacturing combined due to data release restrictions 